\title{
OM MUSEER OCH KYRKOR
}

Museer liknas vid kyrkor, de har med sin sakralisering av de skönaste och yppersta resultaten av människans formförmåga övertagit kyrkans civiliserande roll i en profan tid. Betraktandet av utvalda ting skulle, var det tänkt, ingjuta framstegstankens etos i människors sinnen.

Men kanske används den här liknelsen inte längre så ofta - i stället inverteras den: kyrkornas andliga fostrarroll tonas ned, kyrkornas viktigaste uppgift, hävdas det allt oftare, är som museer för historiska och estetiska värden. Museernas roll har samtidigt förändrats i det moderna samhället. De har utnämnts till bildningsinstitutioner som i likhet med skolan har formandet av ett demokratiskt etos som sin uppgift. Istället för det ovanliga, auratiska och okända, hyllas det vanliga, vardagliga och igenkännliga. Kvaliteter eftersträvade även i samlande och utställande.

Motröster har hörts (avpedagogisera museerna; släpp föremålen loss ur beskäftiga förklaringars tvångströjor). Svante Beckman raljerar i essän Vad vill staten med kulturarvet över den statliga kulturutredningens fäfänga brottning med kulturarvsbegreppet. Utredarna, fann han, hade svårt att rationellt motivera kulturarvspolitiken - eller med Beckmans ord - «utredarna kunde inte räkna ut hur man kan tala om den på ett anständigt modernt sätt». Själv stannar han vid det gammalmodigt irrationella begreppet helgd som det avgörande mervärdet i företeelser som kulturarvspolitiken vill skydda. Upplevelsen av kulturminnena ska väcka den känsla av helgd som är central för ett samhälles ordning och bestånd.

I senaste numret av amerikanska Museum News (May/June 99) fastslår en marknadsundersökare, Neil Kotler, att museerna för att ha någon chans att hävda sig måste definiera en besökslockande profil längs en upplevelseskala som från överraskning (excitement) via lekfullhet (playfulness) och betraktande (contemplation) sträcker sig till inlärning (learning). Medan överraskningen i skalans ena ytterända är sinnlig (visceral!) uppnås stegvist genom emotionell stimulans den andra ytterändans kognitiva position. Särskild uppmärksamhet ägnar Kotler den kontemplativa fasen, som länge varit försummad. Eftersom 'celebration' och 'awe' (vördnad, helgd?) så påtagligt saknas i massmedia bör just dessa värden uppmärksammas och 
odlas som profilskapande museiattraktion. Museibesökare söker i själva verket i museernas salar sådana värden (genom 'celebratory experiences'), som tidigare hört samman med kyrka och religionsutövning. Lyft alltså fram kulturarvets helgd-potential i exponering och marknadsföring!

Än mer överraskande möter i samma tidskrift uppgiften att museer helhjärtat deltar i kampanjen att upprätta trygga samlingsplatser ('safe places') i amerikanska samhällen, särskilt för ungdomar efter skoldagens slut. Programmet, 'America's Promise', lanserades 1997 av ett (levande) amerikanska presidenters toppmöte. Det vill uppmuntra amerikanska medborgare att genom frivilliga insatser förbättra livskvaliteten för nationens ungdomar genom att erbjuda trygga tillflykter för att befordra kunskap och mognad. Museifrid avlöser kyrkofrid. Är kyrkometaforen mogen för restaurering? ***

Att erbjuda en självbild som kan bidra till att hålla en samhällsgemenskap levande kan vara ett sätt att beskriva det humanistiska museets funktion. Eller att rikta uppmärksamheten på förbisedda självbilder som ännu inte fått plats i offentlighet och historia. Avsikter som gärna tenderar mot en sakraliserande övertalning knuten till konkretiserande emblem - ting och bilder - från det förflutna eller samtiden.

En affinitet av det slaget avtecknar sig i bakgrunden till Brennas, Nissens, Palmqvists, Parkingtons och Prosalendis uppsatser om kulturarvs konstruktion och användning i vitt skilda tider och på vitt skilda platser. Liksom i Adotevis klassiker.

Den glanslösa strävan att samla och redovisa komplexiteten i en samhällsbildning och dess ständigt skiftande uppsyn, ter sig sällan lockande men är inte desto mindre ett allt tydligare och angelägnare samhällsuppdrag för museerna. Vi kan reflektera över vanskligheterna med sådana intentioner vid läsningen av Clarkes, Gaards, Illeris, Olofssons, Paludan-Müllers och Rekdals bidrag.

Peter Clarkes och Helene Illeris texter presenterades vid seminariet From Education to Cultural Experience i Norrköpings konstmuseum nov. 1998; Brita Brennas och Hilde Gaards texter vid Instit. för dokumentationsvetenskap i Tromsö, okt. 1998. Carsten Paludan-Müllers och Bruno Ingemanns uppsatser tillkom inom Jette Sandahls museologiska nätverk; Prosalendis och Parkingtons för museidagar i Umeå, Knowledge for Friendship, dec. 1998. 